\title{
Collecting evidence on the use of parliamentary oversight tools: A South African case study
}

\begin{tabular}{|c|c|}
\hline $\begin{array}{l}\text { Authors: } \\
\text { Wilhelm Janse } \\
\text { Rensburg }{ }^{1} \\
\text { Francois Vreÿ } \\
\text { Theo Neethlin }\end{array}$ & $\begin{array}{l}\text { van } \\
\text { (1) } \\
g^{3}\end{array}$ \\
\hline $\begin{array}{l}\text { Affiliations: } \\
{ }^{1} \text { Faculty of Mil } \\
\text { Stellenbosch } ~ \\
\text { Saldanha, Sou }\end{array}$ & $\begin{array}{l}\text { itary Science, } \\
\text { University, } \\
\text { th Africa }\end{array}$ \\
\hline $\begin{array}{l}{ }^{2} \text { Security Instit } \\
\text { Governance a } \\
\text { in Africa (SIGL } \\
\text { Stellenbosch } ~ \\
\text { Stellenbosch, }\end{array}$ & $\begin{array}{l}\text { ute for } \\
\text { nd Leadership } \\
\text { A), } \\
\text { Jniversity, } \\
\text { South Africa }\end{array}$ \\
\hline $\begin{array}{l}{ }^{3} \text { Department } \\
\text { Studies and G } \\
\text { Faculty of Hun } \\
\text { University of } t \\
\text { Bloemfontein, }\end{array}$ & $\begin{array}{l}\text { of Political } \\
\text { overnance, } \\
\text { nanities, } \\
\text { he Free State, } \\
\text { South Africa }\end{array}$ \\
\hline $\begin{array}{l}\text { Correspondin } \\
\text { Wilhelm Janse } \\
\text { wilhelmjvr@g }\end{array}$ & $\begin{array}{l}\text { g author: } \\
\text { van Rensburg, } \\
\text { mail.com }\end{array}$ \\
\hline $\begin{array}{l}\text { Dates: } \\
\text { Received: } 13 \\
\text { Accepted: } 05 \\
\text { Published: } 06\end{array}$ & $\begin{array}{l}\text { ug. } 2019 \\
\text { Fec. } 2019 \\
\text { Feb. } 2020\end{array}$ \\
\hline $\begin{array}{l}\text { How to cite th } \\
\text { Van Rensburg, } \\
\text { \& Neethling, T } \\
\text { 'Collecting evi } \\
\text { use of parliam } \\
\text { oversight tools } \\
\text { African case st } \\
\text { Evaluation Jou } \\
\text { https://doi.or } \\
\text { v8i1.424 }\end{array}$ & $\begin{array}{l}\text { is article: } \\
\text { W.J., Vreÿ, F. } \\
\text {, 2020, } \\
\text { dence on the } \\
\text { entary } \\
\text { s: A South } \\
\text { udy', African } \\
\text { rnal 8(1), a424. } \\
\text { s/10.4102/aej. }\end{array}$ \\
\hline $\begin{array}{l}\text { Copyright: } \\
\text { (c) 2020. The } A \\
\text { Licensee: AOS } \\
\text { is licensed unc } \\
\text { Creative Comr } \\
\text { Attribution Lic }\end{array}$ & $\begin{array}{l}\text { uthors. } \\
\text { IS. This work } \\
\text { der the } \\
\text { nons } \\
\text { ense. }\end{array}$ \\
\hline Read online: & \\
\hline 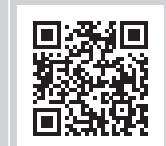 & $\begin{array}{l}\text { Scan this QR } \\
\text { code with your } \\
\text { smart phone or } \\
\text { mobile device } \\
\text { to read online. }\end{array}$ \\
\hline
\end{tabular}

Authors:

Rensburg ${ }^{1}$ (1)

Francois Vrey ${ }^{2}$

Neethling ${ }^{3}$

Stellenbosch University,

Saldanha, South Africa

in Africa (SIGLA),

Stellenbosch University,

${ }^{3}$ Department of Political

Studies and Governance,

Faculty of Humanities,

University of the Free State,

Corresponding author:

Wilhelm Janse van Rensburg,

Dates:

Received: 13 Aug. 2019

Accepted: 05 Dec. 2019

How to cite this article:

Van Rensburg, W.J., Vreÿ, F.

\& Neethling, T., 2020,

use of parliamentary

oversight tools: A South

African case study', African

v8i1.424

Copyright:

C) 2020. The Authors.

is licensed under the

Creative Commons

Attribution License.

mobile device
to read online.
Background: Parliament, through its oversight function, plays a central role in holding the executive to account. In South Africa's 2014 Defence Review policy document, it was stated that the 'Defence Force is in a critical state of decline'. This brings about the question whether the South African Parliament effectively held the executive to account regarding developments around defence.

Objectives: The article aims to gather evidence on the use of oversight tools by the South African Parliament over a 20-year period, within the post-1994 democratic dispensation, in order to determine the broader trajectory of parliamentary defence oversight.

Method: To determine the trajectory of oversight, this article gathered evidence on the use of internationally recognised parliamentary oversight tools by South Africa's two parliamentary defence committees from 1994 to 2014. The period allows for a 20-year review of oversight of defence, inclusive of four full parliamentary terms. Evidence was collected on parliamentary debates, questions, special inquiries, oversight visits and the use of external audits as oversight tools.

Results: The article found that tools were used with varying degrees of success. Results for research on each oversight tool is discussed.

Conclusion: Based on evidence on the use of oversight tools, this article concludes that over a 20-year period there was a declining trajectory in parliamentary oversight of the defence portfolio. The proven applicability of the criteria utilised in this article can serve to inform evaluations of the effectiveness of parliamentary oversight, specifically at committee level.

Keywords: Parliamentary oversight; Evidence gathering; Civil-military oversight tools; Parliament of South Africa; Military oversight.

\section{Introduction}

'Who guards the guardians?', asked 1st-century Roman poet Juvenal. In parliamentary democracies, with systems of checks and balances of power, parliaments can be considered guardians of governmental accountability and transparency. Yet, how is it ensured that parliaments fulfil their function well enough to ensure elevated levels of accountability and transparency? Whilst the democratic process itself ought to ensure a degree of responsiveness and effectiveness, continued evaluation from parliaments can contribute to ensuring greater responsiveness in interelection periods.

Oversight represents a key function of parliaments in a democratic system of checks and balances. Oversight joins two core concepts: accountability and transparency (Bucur-Marcu 2009; Hänggi 2003; Yamamoto 2007). The aim of parliamentary oversight is to ensure transparency in governance and to keep government accountable to the electorate (Fisher 1998:44). Whilst a number of institutions, such as ombudspersons and audit institutions, fulfil the function of oversight, discussion on public accountability often highlights the central role of parliaments (Olson et al. 2008; Yamamoto 2007). It is argued that parliaments are effective oversight institutions because of a unique set of tools available to assist in fulfilling the oversight responsibility. These include, inter alia, parliament's ability to express views on the public sector and its policies, Parliament's power to remove certain office bearers, inquests through committees of inquiry, inquests through specialised parliamentary committees and public hearings (Damgaard 2000; Yamamoto 2007). Existing literature further highlights the importance of parliamentary committees in the oversight process. It is commonly held that committees are the 'engine rooms' of Parliament and contribute substantially to its effectiveness (Ngculu 2003:180).

Note: Special Collection: 9th AfrEA International Conference 2019 
Malcolm Shaw (1998:225) also points to 'the universality of committees' and the value of having an issue-focused oversight capacity. However, both Shaw (1998:238) and Yamamoto (2007:12) caution that committees are not universally effective.

The overview above points to parliaments' oversight potential, but contrasts this potential with questions regarding the universal effectiveness thereof. This contrast raises the need for evaluation of the effectiveness of parliamentary oversight. The South African Parliament's oversight of the defence portfolio provides a succinct case study to review long-term oversight activities at committee level. This case study is based on the dichotomy emanating from the Department of Defence's (DOD) latest long-term policy and planning document, the 2014 Defence Review. The Review (Defence Review Committee 2014) provided a disconcerting summary, noting that 'the Defence Force is in a critical state of decline'. However, parliamentary oversight, through the insurance of accountability and transparency, ought to have been an essential component in preventing such departmental decline. As such, the statement raises questions about the effectiveness and impact of parliamentary oversight of the military in South Africa.

\section{Research aim and design}

The primary aim of this article was to gather evidence on the use of oversight tools by the South African Parliament over a 20-year ${ }^{1}$ period within the post-1994 democratic dispensation in order to determine the broader trajectory of parliamentary defence oversight. From the existing literature, it is evident that parliaments, notably through committees, can ensure elevated levels of accountability and transparency. Through the gathering of evidence from parliamentary committees' oversight activities, the article provides insights into the standing of parliamentary oversight of the military in South Africa. By determining the standing of parliamentary oversight of the military, the article provides two practical outflows with broader application. Firstly, evidence gathered on the use of oversight tools can inform broader and continuous evaluation of parliamentary oversight of the military in South Africa. Secondly, this evidence-gathering exercise can be replicated in various parliamentary committees, other than defence, to aid evaluations on parliamentary oversight. To facilitate this outcome, the article is structured chronologically. Firstly, it identifies the most common criteria for collecting evidence on parliamentary oversight tools and, secondly, it applies the criteria to the South African Parliament's defence committees.

The article was designed as a 'case study', that is, a study of a single unit of analysis (Parliament) with multiple variables (Yin in Babbie \& Mouton 2011:281). Yin (2009:47) notes that single case-study designs are appropriate in a number of instances, including when a single case is representative of many other cases. Case studies also work well with elevated levels of information availability (Gerring 2006:57). A casestudy design was therefore appropriate as information was drawn from various democratic parliaments and studies of oversight at such institutions. Data on parliamentary oversight of the military in South Africa were also widely available and often contained in official records that contributed to the accuracy thereof. Furthermore, in keeping with the characteristics of case studies, this article focused on validating the existing theory rather than aiming to discover new theories (Yin 2009:47). By using a case-study design, the article can compare the parliamentary oversight of the military in South Africa with the existing protocols and conventions of good practice, and within the parameters of established theory.

Data collection methods for this article adhered to the requirement of case studies (to make use of multiple sources of data) and fall within the qualitative research paradigm. Primary data sources included official parliamentary documentation, such as the Announcements, Tablings and Committee (ATC) reports as well as parliamentary questions. Secondary data sources played a key role in filling information gaps where primary sources may be lacking. For example, where official committee minutes were not available, information from quality secondary sources, such as the Parliamentary Monitoring Group (PMG), a non-profit organisation, was used to fill the gap. Although extremely valuable sources of information, these primary and secondary sources noted above often fail to capture the finer nuances of the political setting at the time. Additional evidence was therefore gathered by conducting unstructured qualitative interviews. A total of 15 interviews were conducted ${ }^{2}$, including nine former Members of Parliament (MPs) who served on Parliament's defence committees, former parliamentary officials and sector-specific academics. Notably, the mix of MPs interviewed allowed for both governing and opposition views from each parliamentary period between 1994 and 2014. The selection of interviews was based on a 'nonprobability sampling' approach. Primarily, judgemental sampling was used to select interviews whereby respondents 'are selected on the basis of the researcher's judgement about which ones will be most useful or representative' (Babbie 2013:128). In addition, snowball sampling was used (Babbie 2013:129), which allowed interviewees to suggest additional relevant persons to be interviewed.

The main limitation of this study in terms of data collection revolves around the availability of formal parliamentary documents. Request to officials at Parliament revealed that official parliamentary minutes on committee meetings were not readily available or have been lost, especially for the first two parliaments. As such, committee meeting minutes from the PMG were utilised. However, PMG only commenced with the recording of minutes in January 1998, and limited data were available on committee meetings before this date.

2.Interviews were conducted after the ethical clearance was received from Stellenbosch University on 29 March 2016. 


\section{Conceptual framework}

This article lies at the nexus between two theoretical bases, namely, theories of democracy and civil-military relations. The link between the military, which is in its very nature a non-democratic institution, and democracy may not seem apparent (Cawthra \& Luckham 2003:305). However, Burk (2002:9-11) highlights the link between civil-military relations and liberalism by noting the security of individual rights as one of the cornerstones of liberalism. This requirement must, however, be balanced with another liberal requirement, that power is not abused and sovereignty remains. Thus, there is a need to ensure that the military is powerful enough to fulfil its protection function, but not too powerful as to override democratic civilian control of the country (the will of the people). Parliament plays a key role in maintaining this balance, specifically through the oversight process. The oversight role is also central to ensuring healthy civil-military relations as it regulates the subordination of the military to civilian political leadership and ensures minimal involvement of the military in politics.

Prior to 1994, civil-military relations in South Africa were characterised by a lack of effective civil control of the military. In keeping with more democratic requirements, post-1994 South Africa witnessed the adoption of a model that emphasised civil control of the military. It made specific provision, notably through the 1993 Interim Constitution and the 1996 Constitution, for parliamentary oversight in this process (Heinecken 2019:67-68). The establishment of two parliamentary committees to oversee defence matters provided practical means for effective civil oversight.

The two underlying theories can be used to explain the trajectory of parliamentary defence oversight in South Africa. Liberal democracies require openness and transparency around the military and, through a system of checks and balances, the effective balancing of military power. For these characteristics to manifest, effective parliamentary oversight aided by the use of oversight tools is essential. Similarly, civil-military relations in a democratic setting require the effective civil control of the military, which is attained, in part, through parliamentary oversight. An analysis of the use of oversight tools to oversee defence matters will therefore provide input on the status of civil-military relations in South Africa. It will also provide insights into the degree to which the liberal democratic ideals of openness and transparency were achieved at parliamentary level regarding defence matters.

\section{Research structure: Criteria for evidence collection}

Consensus on the broad tools available for parliamentary oversight seems to exist amongst scholars. Identified tools most commonly referenced include committee hearings, hearings in the plenary (chamber), commissions of inquiry (including ad hoc committees), parliamentary questions, question time (in the plenary) and interpellations ${ }^{3}$. The identification of these parliamentary oversight tools provides for parameters within which to locate a set of tools applicable to oversight of the military. Research on such oversight has been conducted by, inter alia, three reputable international institutions: the Inter-Parliamentary Union (IPU), the Centre for the Democratic Control of the Armed Forces (DCAF) and Transparency International. A review of analyses by these institutions points to five specific means (tools) of oversight that are central to the oversight of the military. These tools form the basis of evidence collection in this article:

- Parliamentary debates: whilst debates on defence occur at plenary and committee level, this article focuses on the oversight by committees. The aim of committee debates is to impact a committee's collective decision on a specific aspect of defence governance. Such debates allow a unique opportunity for obtaining facts on military affairs from the executive or addressing defence-related aspects of major concern. It is usually characterised by a presentation from officials, policy statements or other planning initiatives from the executive (Born 2003:77; Yamamoto 2007:62). Debates, when done publicly, also enhance public interest in specific aspects of defence and security.

- Parliamentary questions: questions from MPs to the executive can either be submitted orally or in written form. Its significance lies in the opportunity it affords individual members to raise military-related concerns and receive timely responses. Given the public availability of responses, it also allows for public interest in defence matters (Born 2003:79; Yamamoto 2007:49-59).

- Special defence inquiries: special inquiries are characterised by in-depth engagement on specific defence-related aspects. During special inquiries, parliamentary committees often engage expert opinions and may subpoena certain role-players. Following the inquiry, a formal report is published. Defence inquiries of this nature can be done by parliamentary defence committees, multiple committees, subcommittees or ad hoc committees. In the case of the latter, special powers of inquiry can be allocated to committees (Born 2003:80; Yamamoto 2007:39-42).

- Oversight visits and study tours: oversight visits for defence purposes relate to visits by MPs (often as a committee) to military units and/or operational deployment areas in an effort to familiarise themselves with matters at ground level (Cover \& Meran 2013:43). Study tours, also mostly conducted at committee level, often include foreign or local tours to study examples of policy implementation and sharing of best practice (Agnihotri 2011:7; Sisulu 2012).

- The use of external audit: external audit may be outside the scope of parliaments, but can play an important role in effective oversight. Transparency International (Cover \& Meran 2013:10) notes that parliaments can assist in

3.Interpellations differ from normal parliamentary questions in that they relate strongly to a vote of no confidence. While normal parliamentary questions require strongly to a vote of no confidence. While normal parliamentary questions require
separate motions of a vote of no confidence, interpellations have, as an immediate subsequent step, a vote of no confidence (Döring 1995:199). 
lowering corruption risks in the defence domain by including external audit analysis in their oversight. Practically, this would include calling external auditors (or state auditors) to appear before parliamentary committees or requesting in-depth analysis from such auditors.

\section{Ethical considerations}

Ethical clearance to conduct the study was obtained from Stellenbosch University on 23 March 2016 (Ethical clearance number: REC-050411-032).

\section{Key findings}

This article collected evidence on the use of oversight tools in the exercising of parliamentary oversight over the military in South Africa. Evidence was largely gathered from the work of the two parliamentary defence committees, namely, the National Assembly's Portfolio Committee on Defence and Military Veterans (PCDMV) and the Joint Standing Committee on Defence (JSCD) consisting of MPs from the National Assembly and the National Council of Provinces (NCOP). Evidence was gathered on parliamentary debates, questions, special inquiries, oversight visits and the use of external audits as oversight tools.

The first key finding relates to the primary aim of the article that sought to determine the broader trajectory of parliamentary defence oversight. Evidence collected on the use of parliamentary oversight tools clearly reveals that these tools were not used optimally. The use of external audit opinions and oversight visits reflects positive utilisation during some parliamentary periods. However, committee debates on defence as well as in-depth parliamentary inquiries showed a declining trend. A key contributor to the underutilisation of these oversight tools was the inactivity of the JSCD during the period under review. The use of written and oral questions also revealed concern, with interviewees raising questions around the poor usage of this oversight tool. Given the centrality of these tools for the broader oversight efforts, the article finds a negative or declining trajectory related to Parliament's oversight of the military between 1994 and 2014. This trajectory also reflects on civilmilitary relations in South Africa and points to potential shortcomings in effective civil control of the military. The article therefore substantiates findings by, for example, Heinecken (2011) who notes a growing civil-military gap in South Africa.

Although not the primary aim of the article, evidence collected provide some insights into possible reasons for the underutilisation of oversight tools in the defence portfolio. Reduced JSCD activity could, for example, be ascribed to administrative arrangements at Parliament. However, evidence reveals a larger concern relating to the perception of a lack of political will to conduct oversight. The perception exists amongst some MPs interviewed that there was a relative decline in the willingness to hold the executive to account. Evidence collected around the use of parliamentary questions confirmed the apparent unwillingness to hold the executive to account, notably on the part of MPs from the ruling party. Some interviewed MPs thus raised the concern that the differentiation between Parliament and the executive became convoluted and accountability suffered as a result of party loyalty. Linked to the decline in keeping the executive to account, there was a noticeable increase in non-responsiveness from the DOD based on 'security considerations'. This reflects poorly on the desired liberal democratic parliamentary outcomes of accountability and transparency.

The second finding relates to the secondary aim of the article, namely, the replication of this evidence-gathering exercise in parliamentary committees other than defence. In this sense, the structure of the article and the criteria for evidence collection provide a guideline for evidence gathering. As noted, consensus exists on the parliamentary tools for oversight of the military to include debates, questions, special inquiries, oversight visits and tours, as well as the use of external audit. By collecting evidence on the use of these oversight tools over a 20-year period, the article confirmed the relevance of these tools as a means of gauging the trajectory of oversight. Sufficient qualitative evidence could be collected to provide a clear indication of the status of oversight. The article also found that all generally accepted parliamentary oversight tools were used to oversee the military in South Africa, although with varying degrees of success. The article therefore presents a concise set of oversight tools that can be tracked across parliamentary committees to provide insights into the long-term effectiveness of oversight efforts.

\section{Discussion}

Based on the recognised tools for parliamentary oversight of the military, the following sections provide an overview of the utilisation of each tool over a 20-year period by the JSCD and PCDMV. Discussions are structured to highlight the broad trajectory of oversight and to demonstrate the type of evidence to be collected for a potential evidence-based evaluation.

\section{Committee debates on defence}

Qualitative interviews with MPs revealed limited attention to defence debates at plenary level between 1994 and 2014. As such, more robust debate at committee level, the 'engine rooms of Parliament', ought to be expected. Whilst frequent defence committee meetings in themselves are not an indicator of high levels of oversight, parliaments with elevated levels of oversight of defence are often characterised by more frequent meetings. Figure 1 provides an overview of PCDMV and JSCD meetings between 1998 and 2013, depicting four key deductions. Firstly, there has been a steady decline in the activity of the JSCD. Whilst the JSCD was still actively involved in deliberations around the 1998 


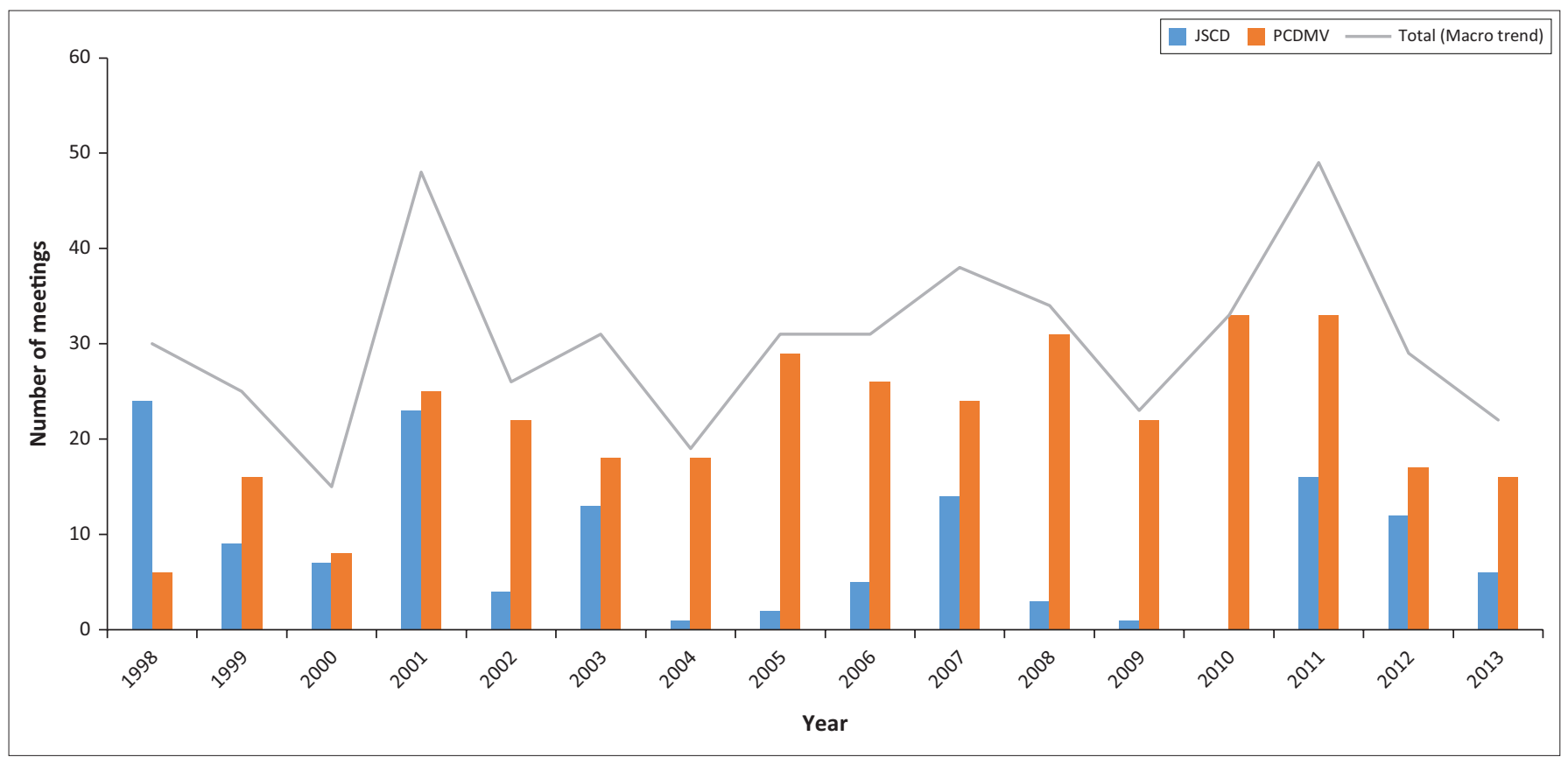

Source: Compiled from Committee Minutes of Parliamentary Monitoring Group (1998-2013)

FIGURE 1: Macro-trend in Joint Standing Committee on Defence and Portfolio Committee on Defence and Military Veterans meetings (1998-2013).

Defence Review, its subsequent activity became very limited. Secondly, the period when the JSCD were more active related to specific defence aspects, such as inquiries into the Strategic Defence Procurement Package (SDPP) in 2001, military veterans' benefits in 2007 and administrative meetings related to the programme and mandate of the JSCD in 2011. Thirdly, the reduction in JSCD activity was offset, in part, by an increase in PCDMV activity from 2000 onwards. Fourthly, overall PCDMV and JSCD activity witnessed a sudden decline in 2012 and 2013. The latter is of specific concern as it reverses the steady increase in engagements by the PCDMV over the preceding years.

Figure 2 provides a further analysis of JSCD and PCDMV meetings between 1998 and 2014. It differs from Figure 1 in that it also denotes, under the x-axis, the number of joint meetings between the two committees as well as meetings that were purely administrative in nature (such as meetings where only minutes were adopted or chairpersons were elected). Figure 2 therefore provides a true macro-trend indication of the number of unique defence oversight meetings held at committee level. Three additional deductions emerge from this analysis. Firstly, except for the 2001 joint meetings on the SDPP, joint meetings between the JSCD and PCDMV were highly underutilised. Secondly, the number of purely administrative meetings (where no oversight took place) increased during the Third and Fourth parliaments. This is specifically true of the JSCD. Finally, the broader view of unique defence oversight meetings between 1998 and 2013 reflects a moderate increase in activity after 2000 .

From the above observations regarding defence committee activity, it can be argued that the overall frequency of parliamentary inquiry on defence was significantly undermined by the inactivity of the JSCD. The JSCD became reactionary throughout the period 1998-2014 and undermined the ideals of continuous oversight. During the years when the JSCD was slightly more active, higher levels of overall engagement on defence matters were achieved. For example, when the PCDMV and JSCD operated at elevated capacity, a joint average of up to 40 meetings annually was achieved. This was, however, an exception to the generally limited number of engagements. Furthermore, the sudden decline in PCDMV and JSCD activity in 2012 and 2013 is of concern.

The trends observed and deductions made based on the data presented correlate with observations noted during interviews. Given limited information on committee meetings prior to 1998, additional data on committee activity in the First Parliament were obtained through interviews. Two MPs noted that committee meetings in the First Parliament were regularly held and well organised. In general, such meetings were attended by a full complement of MPs serving on the committees. Another MP noted that this intensity remained in the First and Second parliaments. One MP interviewed, however, stated that in the Second Parliament both the committees were not active enough, particularly the JSCD. The perception of decreased effectiveness of the committees became stronger in the Third Parliament. An academic interviewed underscored these challenges by noting an increasing concern regarding the lack of robust debate on military affairs. This coincides with observations made by an MP that, from the Third Parliament onwards, robust debate declined and that it was characterised by efforts to protect the executive and not to necessarily hold it to account. 


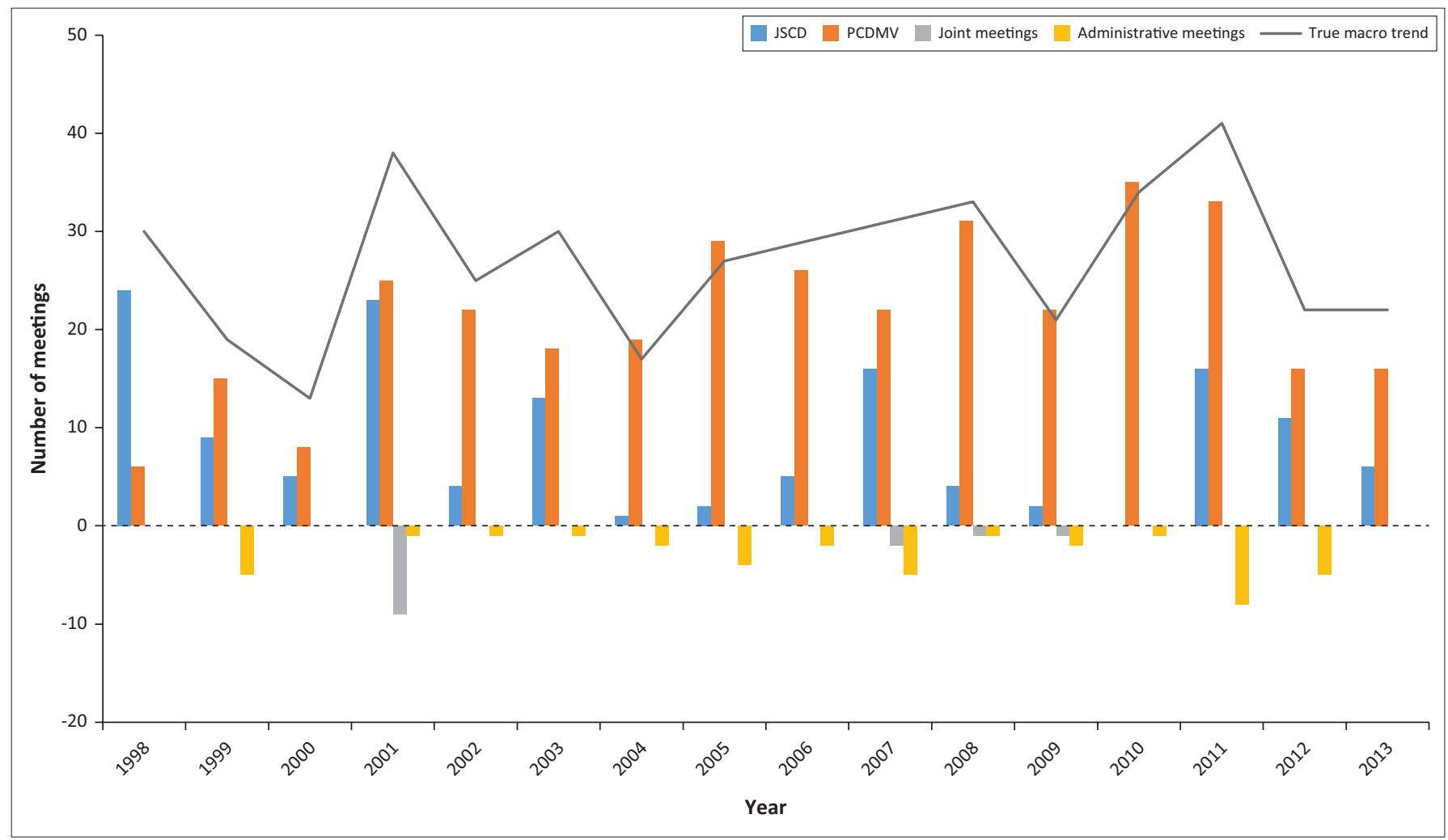

Source: Compiled from Committee Minutes of Parliamentary Monitoring Group (1998-2013)

FIGURE 2: True macro-trend for Joint Standing Committee on Defence and Portfolio Committee on Defence and Military Veterans meetings (1998-2013).

Heavy criticism was also forthcoming regarding JSCD and PCDMV activity in the Fourth Parliament. For example, an MP noted that ample time in the parliamentary programme existed for thorough engagement on the 2014 Defence Review, but these periods were not utilised. According to an MP interviewed, this work-rate compares poorly to that of other committees in Parliament. Members of Parliament also found debate at committee-level stifling. Practically, MPs noted that robust engagement between members and the DOD was inhibited by insufficient opportunity to pose follow-up questions or where meetings were simply cut short. An MP also claimed that when written follow-up responses were requested, these were not submitted to Parliament and/or did not reach MPs.

Despite criticism, interviews provided some context for the observed decline in JSCD activity. Primarily, a change in the nature of the JSCD was noted. An MP interviewed recalled that the committee was established in 1993 as a joint committee to focus on the 'joining' of various military forces (integration), rather than a joint venture that included the two houses of Parliament. However, the size of the committee became a concern that impacted the ability of the committee to function optimally. Concerns regarding scheduling were also identified from the Third Parliament onwards. The attendance of NCOP members became problematic as their programme differed from that of the National Assembly. For example, various former Members of the JSCD claimed that meetings were scheduled on Friday mornings when most MPs have already left to their various constituencies. This resulted in the JSCD seldom forming a quorum.
The overall trend in parliamentary debates on defence reflects some growth, but general inconsistency. Plenary debates remained limited and JSCD activity showed a decline over the 20-year period. Whilst PCDMV activity increased over time, a negative trend was observed towards the end of the Fourth Parliament.

\section{Parliamentary defence questions}

Between 1994 and 2014, a total of 2045 questions on defence were posed by MPs. Figure 3 reveals that questions regarding defence were asked mostly by members from the National Assembly. This may be considered in line with the fact that defence is a national competency and only occasionally affects matters of provincial importance. The number of questions by MPs from the NCOP seems to correlate with the activity of the JSCD (see Figure 2), as the JSCD includes MPs from the National Assembly and the NCOP. Whilst initially posing more frequent questions on defence between 1994 and 1999, the number of questions by NCOP MPs decreased after that, with marginal increases in 2001, 2007 and 2011, correlating with the trend of JSCD activity. It could therefore be argued that the decline in JSCD activity directly affected NCOP interest and oversight in defence matters. On the contrary, questions by the National Assembly MPs remained consistent, with sporadic increases of questions between 2001 and 2003 as well as between 2011 and 2013.

Interviews provided further insights into the effectiveness of parliamentary questions on defence between 1994 


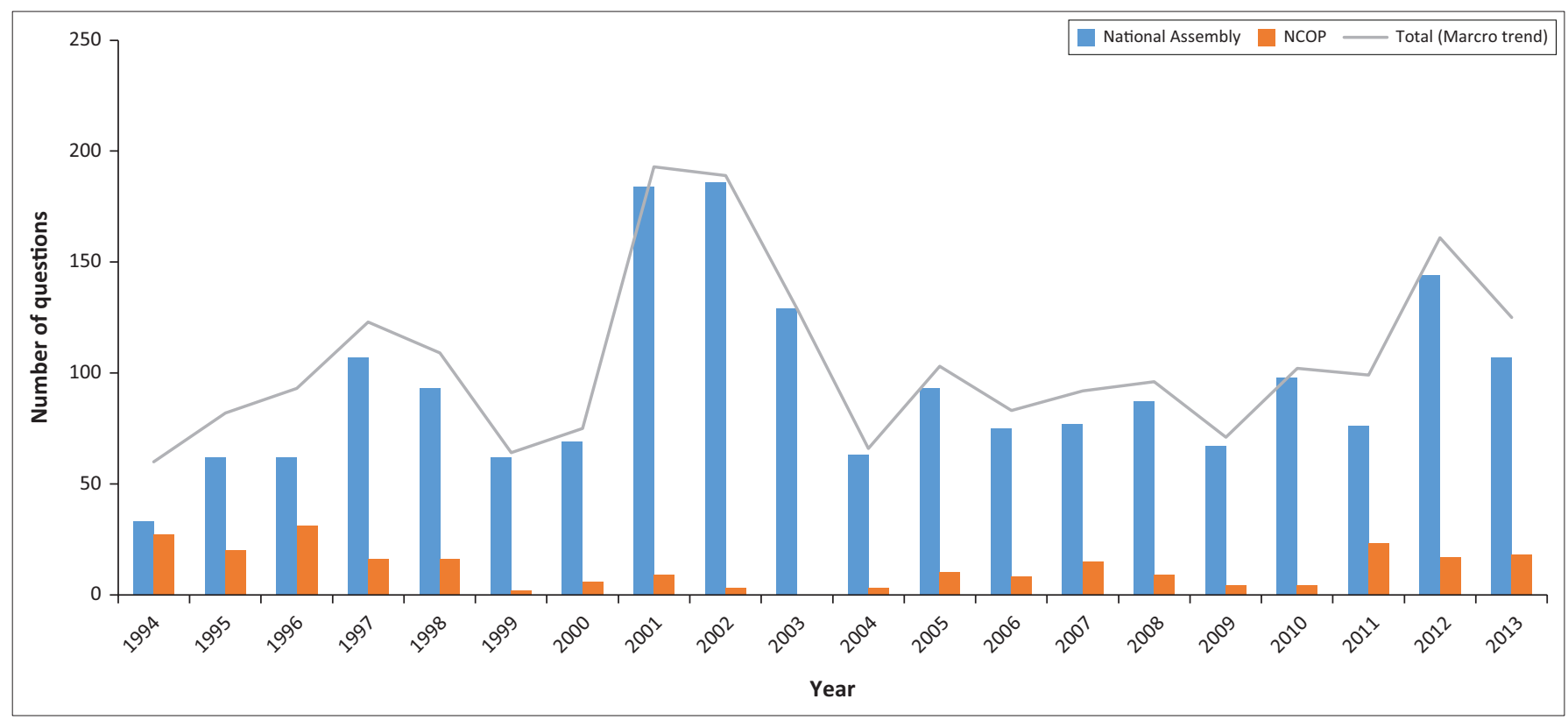

Source: Compiled from Questions and Replies (Library of Parliament)

FIGURE 3: A 20-year trend - Questions per house of Parliament (1994-2013).

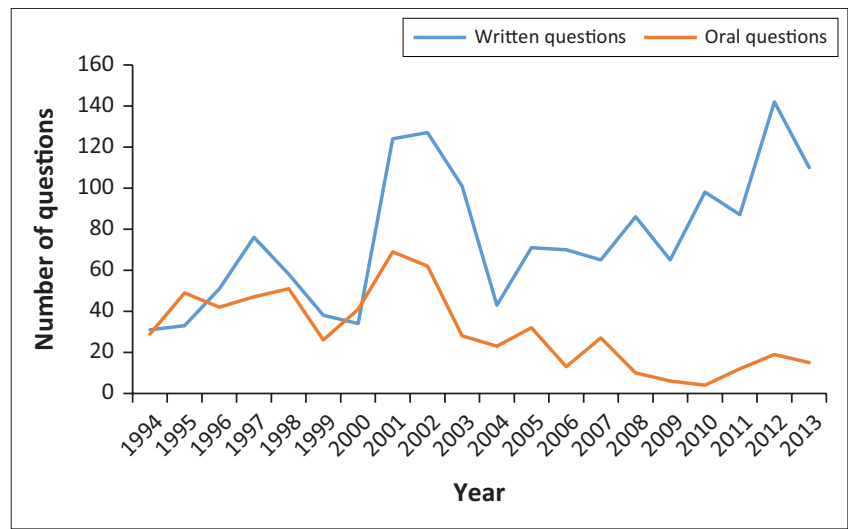

Source: Compiled from National Assembly and National Council of Provinces Question Papers (1994-2013)

FIGURE 4: A 20-year trend - Written and oral questions (1994-2013).

and 2014. An MP interviewed highlighted the importance of noting that questions are posed by individuals. As such, parliamentary questions are often more political in nature. Two MPs recalled that, in the First and Second parliaments, questions were well utilised (specifically from an opposition point of view) and the executive always provided responses. However, questions were arguably not utilised effectively from the Third Parliament onwards. A key concern noted by an interviewee is the fact that responses to questions were often deemed 'classified'. From around 2007 or 2008, questions that were previously answered in detail became classified as it related 'operational matters'. A similar concern was noted by another MP, who stated that some questions were simply not responded to or superficial or incomplete answers were provided. Interviews revealed that this trend carried forward into the Fourth Parliament. Questions were thus underutilised by MPs, specifically in terms of the substance, and often only used for political grandstanding.

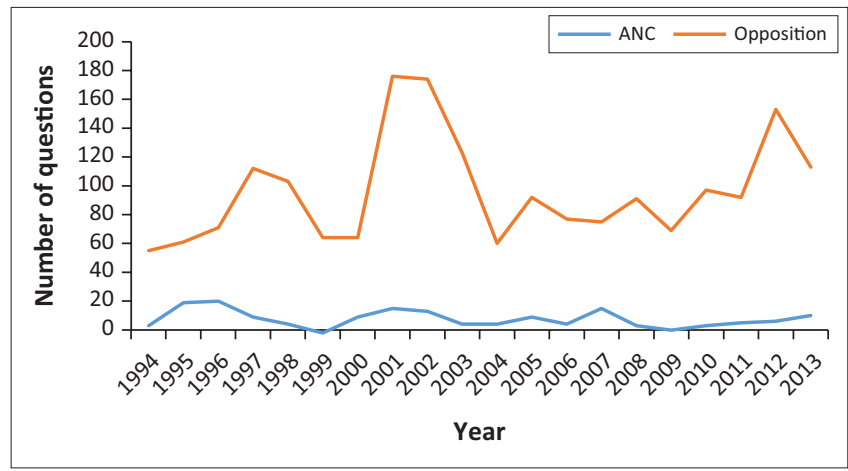

Source: Compiled from National Assembly and National Council of Provinces Question Papers (1994-2013)

FIGURE 5: A 20-year trend - Questions by ruling party and opposition (1994-2014).

Figure 4 shows the higher frequency of written questions compared to oral questions. This is in line with international norms whereby time for oral questions is often limited. Of interest in the South African case is, however, the significant decrease in oral questions to the Minister of Defence throughout the 20-year period. A widening gap between written and oral questions is noted from 2004 onwards. It can be argued that, in the Third and Fourth parliaments, the decreasing utilisation of oral questions undermined the overall effectiveness of using questions as a means of ensuring accountability. One MP interviewed noted that the limited utilisation of oral questions is because of time restrictions. Not all questions can be answered, and although the executive is required to answer the outstanding questions in writing, opposition MPs are reluctant to go this route and simply submit written questions. Another MP concurred and noted that, during the Fourth Parliament, replies to oral questions simply became prepared statements, notably when the questions originated from ruling party MPs. 
Interviews noted that questions often became used for political grandstanding, and data reflect a significant decrease in oral questions on defence over a 20-year period. This information should be read together with statements by two MPs interviewed that lamented the fact that questions were largely posed by opposition members. This notion is confirmed by data in Figure 5, revealing a decreasing trend in questions posed by MPs from the ruling African National Congress (ANC). The overall number of defence-related questions asked by MPs remained consistent. However, questions by MPs from the ruling party decreased from 124 between 1994 and 2004 to 79 between 2004 and 2014. The majority of these questions were oral questions, and thus asked to a member of the executive during a parliamentary sitting.

The key deduction from the data, and context provided by interviews, is that of increasing written questions amidst decreasing oral questions, with the efficiency of such questions declining over time because of an apparent unwillingness of the DOD to provide comprehensive and transparent answers. Furthermore, the widening gap between the utilisation of questions between MPs from opposition parties and those in the ruling party reduced the impact of parliamentary questions as an oversight tool on defence. The contribution thereof to continued parliamentary oversight of the military thus declined over time.

\section{Special defence inquiries}

Special inquiries, characterised by in-depth engagement on specific defence-related aspects, saw limited utilisation in South Africa between 1994 and 2014. Despite committee minutes lacking for the First Parliament, an MP recalled the establishment of a subcommittee in the JSCD related to the integration process. Parliamentary oversight of the integration process was essential as South Africa sought to amalgamate former opposing military forces into one cohesive national defence force. The use of Parliament in overseeing this process was essential within the framework of the state's focus on establishing democratic civil-military relations (Modise 2003:46-47). The establishment of a subcommittee at parliamentary level thus allowed for indepth analysis of the process. Despite the use of a subcommittee in the First Parliament, special defence inquiries were not widely used thereafter.

Between 1998 and 2004, two limited special inquiries were held. Firstly, in 2001, the JSCD and PCDMV conducted a joint inquiry into the SDPP. Although this can be considered a special defence inquiry, it did not take the form of an independent inquiry by the two committees. Rather, several joint meetings were held between 14 November and 04 December 2001 when briefings were provided to the committees by government's investigating agencies (PMG 2001). Secondly, the JSCD conducted public hearings and at least two meetings on the language policy of the South African National Defence Force (SANDF) in 1999 (PMG 1998a, 1998b). Whilst public and/or expert opinion was sought and this represented a deeper level of inquiry, it still falls short of the criteria set for a special defence inquiry.

Between 2004 and 2014, inquiries were also limited. In 2004, the PCDMV arguably came closest to a special defence inquiry in their follow-up engagements on the 1998 Defence Review. A total of six meetings were held on the Defence Review, including 2 days of public hearings (PMG 2004). Three further meetings were held in 2005, concluding with a meeting held on the White Paper and Defence Review Restructuring (PMG 2005). In 2007, the JSCD conducted a number of hearings on the improvement of services to military veterans. This inquiry was, however, not a specific in-depth inquiry and rather related to the passing of the Military Veterans Act (2011). Furthermore, in 2008 and 2009, three meetings were held regarding unionisation in the SANDF, including a public hearing with the South African National Defence Union (SANDU). Despite the more focused approach of the PCDMV on the matters related to unionisation, no in-depth specific analysis took place and no formal committee report on the matter was drafted.

Whilst some defence-related aspects received elevated levels of scrutiny, special defence inquiries as an oversight tool were underutilised. Not all of these inquiries truly conformed to the requirements of special defence inquiries, as they often did not result in a formal committee report or the stipulation of specific recommendations to the executive. Except for subcommittees on integration in the First Parliament, the PCDMV and JSCD also did not make significant use of subcommittees for in-depth scrutiny of identified concerns. Suggestions on the formation of subcommittees in the Second Parliament did not materialise. Similarly, except for a joint investigation into the SDPP, no ad hoc committees were established to investigate defence matters. 'In-depth' inquiries conducted by the defence committees are therefore in line with its normal oversight functions than a special defence inquiry. These findings were largely confirmed by three MPs, noting limited special defence inquiries and/or the establishment of subcommittees with specific investigative purposes. An MP and academic interviewed also noted that even crucial military events, like Operation Boleas ${ }^{4}$, shootings in military bases and the 2013 SANDF losses in the Central African Republic did not result in special defence inquiries.

\section{Oversight visits and study tours}

Oversight visits to military bases or areas of deployment are crucial for MPs to familiarise themselves with practical concerns. Such visits are largely conducted at committee level. The effectiveness of oversight visits and study tours should ideally be measured through its impact, which is difficult to determine. However, a basic condition for an oversight visit or study tour to have impact is that it has to be 4.Operation Boleas refers to the 1998 SANDF military operations in Lesotho as part of a Southern African Development Community (SADC) peacekeeping force. 
conducted within the Rules of Parliament and concrete recommendations should emanate therefrom. The Rules of Parliament provide a requirement for a report to be submitted to the National Assembly and/or NCOP by any committee on its activities, including oversight visits and study tours. Reports are officially published in Parliament's ATC (Parliament of South Africa 1995:10-11).

A review of the ATCs between 1994 and 2004 reveals that defence committees conducted only one oversight visit during this period for which an official report was published (by the JSCD in 1994). However, committee minutes of both the JSCD and PCDMV between 1998 and 2004 reflect on more oversight visits. At least four visits to military bases and defence industry institutions took place over this period. Nonetheless, no official reports of these visits are reflected in available committee minutes or in the ATCs, and therefore, the direct impact of such oversight visits can be questioned. The Third Parliament witnessed a drastic turnaround in the utilisation of this oversight tool, notably by the PCDMV. In total, the committee conducted at least 10 visits in the Third and Fourth parliaments, mostly to military bases around the country. The JSCD conducted three oversight visits over the same period.

A marked increase in the use of oversight visits and official reporting thereon is visible from 2004 onwards. This is largely attributed to the 13 visits that took place in the Third and Fourth parliaments. The increased utilisation of oversight visits as an oversight tool can be viewed as a positive development. However, the utilisation of this tool is weakened by delays in the submission of formal reports following oversight visits. Following most PCDMV oversight visits in the Third and Fourth parliaments, formal reports were generally only published in the ATC between three and six months after the visit. A further factor that may limit the successful utilisation of this oversight tool is the lack of activity of the JSCD that failed to effectively use oversight visits between 1994 and 2014. There was also a decline in the utilisation of this oversight tool in the Fourth Parliament, with only three oversight visit reports tabled in the ATC compared to seven in the Third Parliament. This is again in line with reduced committee activity of both the JSCD and PCDMV in the latter parts of the Fourth Parliament.

The majority of MPs interviewed generally consider oversight visits to be a positive and constructive oversight tool. Despite this, MPs and academics raised several concerns that tend to undermine the impact of oversight visits. An academic interviewed observed a concern from past oversight visits in that the DOD would 'soft soak' MPs during visits, thus limiting in-depth inquiry. An MP further noted that engagements with DOD personnel are limited by time constraints or by a decision to end oversight activities earlier than planned. An example was mentioned about an oversight visit to an infantry base whereby the chairperson of the delegation stopped the engagement with personnel at the base at lunchtime and MPs returned to Parliament. Committee members were not consulted in this decision. As such, some MPs wish to conduct oversight visits themselves because of the fact that committee visits are often ineffective. However, an MP interviewed lamented the fact that obtaining such permission is often a lengthy process.

Closely related to the use of oversight visits as a parliamentary tool is the conducting of international study tours by committees. Data from Parliament's ATCs revealed that between 1994 and 2014 five such tours were conducted by the PCDMV and JSCD (often jointly). In all cases, formal reports were published in the ATC. An interviewee highlighted the relevant and positive nature of a study tour in the First Parliament to study civil oversight of the military and the integration of forces aboard. One concern that emanated from the data is the delay in the tabling of study tour reports. This has the potential to reduce the impact of such tours. Of further concern is the fact that no study tours were conducted during the Fourth Parliament. The limited number of study tours has a specific impact on oversight of military deployments. For example, an MP stated that it means that the Minister of Defence only received uncontested information on deployments from the DOD itself.

Oversight visits and study tours are crucial tools to broaden MPs sector-specific competence. These tools were increasingly utilised between 1994 and 2014, but a clear reduction is observed in the Fourth Parliament. This challenge is compounded by delays in submitting formal reports and practical challenges manifesting during oversight visits, all of which brings into question the effective use of the oversight tool.

\section{The use of external audit}

The use of external audit is an important tool to enhance the depth of parliaments' oversight capacity. In the South African Parliament, external audit opinions utilised almost exclusively relate to the work of the Auditor-General of South Africa (AGSA). Both defence committees made use of the work of the AGSA in oversight activities between 1994 and 2014. A review of committee minutes reveals significant growth (from a low base) in the use of the AGSA's audits.

Between 1998 and 2004, reports by the AGSA were only referenced three times by the PCDMV. The tool was thus initially used only sporadically. This grew notably during the Third and Fourth parliaments, whereby the AGSA regularly briefed the PCDMV on its audit opinions. During the Third Parliament, for example, MPs made reference to the AGSA's reports annually during engagements with the DOD on its annual reports. Consideration of the AGSA's audit opinion of the DOD's annual report became fully entrenched during the Fourth Parliament through formal presentations to the committee. It should be noted that policy development also encouraged the broader utilisation of the AGSA's audits for 
parliamentary oversight. Both the 2005 National Treasury Guidelines for Legislative Oversight as well as the Manual for Parliamentary Committees emphasise the use of the AGSA's work (National Treasury of South Africa 2005; Plaatjie 2011).

The incremental use of the AGSA's audits also surfaced in interviews. An MP noted that in the Second Parliament, the work of the AGSA was used to limited extent and the committees did not thoroughly use this to impact on its work. The AGSA did, however, play an important role in the SDPP investigations. Another MP confirmed the shift towards broader utilisation of the AGSA's work in the Third Parliament, specifically during annual report hearings. However, the fact that direct engagement between the PCDMV and AGSA only occurs once a year was raised as a concern for other MPs. Furthermore, an MP stated that requests for special audits were never considered by the AGSA. As such, in the context of a 20-year overview, the increased utilisation of the AGSA's work at parliamentary level is a positive contributor to overall oversight; however, room for improvement remains.

\section{Conclusion}

This article gathered evidence on the use of internationally recognised parliamentary oversight tools by South Africa's two parliamentary defence committees between 1994 and 2014. The evidence revealed that tools were used with varying degrees of success. External audit opinions were increasingly utilised, whilst oversight visits also reflected effective use during some parliamentary periods. However, committee debates on defence as well as indepth parliamentary inquiries on defence showed concerning declines over the period. The use of written and oral questions by MPs, although increasing over time, revealed major concerns in the political will of MPs to effectively hold the executive to account. This reflects poorly on liberal democratic ideals of openness and transparency. Based on the review of the use of oversight tools, the article provides evidence of a negative trajectory of parliamentary oversight of the military in South Africa over a 20-year period.

Poor civil oversight of the military also impacts negatively civil-military relations in a democratic setting. The poor use of parliamentary oversight tools contributed to the poor civil oversight of the military and thus impacted negatively the civil-military balance that was envisaged for the post-1994 democratic South Africa. The article therefore substantiates developing theories about the widening civil-military gap in South Africa. In addition, the article provides potential practical contributions as the evidence collected can serve to inform adjustments in parliamentary approaches in an effort to enhance defence oversight. The proven applicability of the criteria utilised in this article can also serve to inform evaluations of the general effectiveness of parliamentary oversight, specifically at committee level.

\section{Acknowledgements}

The author would like to thank the co-authors, Prof. Francois Vrey (SIGLA) and Prof. Theo Neethling (UFS), for their contribution in the finalisation of the original study that gave rise to this publication. The author would also like to thank those who provided critical inputs during discussion on the paper at the 9th AfrEA Conference in Abidjan, Cote d'Ivoire.

\section{Competing interests}

The authors declare that they have no financial or personal relationships that may have inappropriately influenced them in writing this article.

\section{Authors' contributions}

W.J.v.R. is the primary author of the article. He wrote the article with input from and supervision provided by F.V. (SIGLA) and T.N. (UFS).

\section{Funding information}

This research received no specific grant from any funding agency in the public, commercial or non-profit sectors.

\section{Data availability statement}

Data sharing is not applicable to this article as no new data were created or analysed in this study.

\section{Disclaimer}

The views and opinions expressed in this article are those of the authors and do not necessarily reflect the official policy or position of any affiliated agency of the authors.

\section{References}

Agnihotri, V., 2011, 'The role of committees in parliamentary oversight of the executive', in Association of Secretaries General of Parliaments: Panama Session, Inter-Parliamentary Union, Geneva.

Babbie, E., 2013, The practice of social research, Wadsworth, Belmont.

Babbie, E. \& Mouton, J., 2011, The practice of social research, Oxford University Press, Cape Town.

Born, H. (ed.), 2003, Parliamentary oversight of the security sector: Principles, mechanisms and practices, Geneva Centre for the Democratic Control of Armed Forces, Geneva.

Bucur-Marcu, H. (ed.), 2009, Essentials of defence institution building, Geneva Centre for the Democratic Control of Armed Forces, Geneva.

Burk, J., 2002, 'Theories of democratic civil-military relations', Armed Forces \& Society 29(1), 7-29. https://doi.org/10.1177/0095327X0202900102

Cawthra, G. \& Luckham, R. (eds.), 2003, Governing insecurity: Democratic control of military and security establishments in transitional democracies, Zed Books Ltd, London.

Cover, O. \& Meran, S., 2013, Watchdogs? The quality of legislative oversight of defence in 82 countries, Transparency Internaitonal, London.

Damgaard, E., 2000, 'Representation, delegation and parliamentary control', in ECPR Joint sessions: Parliamentary control of the executive, Copenhagen, Denmark, April 14-19, 2000, n.p.

Defence Review Committee, 2014, South African defence review 2014 for parliamentary processes, Department of Defence, Pretoria.

Döring, H. (ed.), 1995, Parliaments and majority rule in Western Europe, University of Mannheim, Mannheim. 
Fisher, H., 1998, The new South African parliamentary committee system: Its role and effectiveness, University of the Western Cape, Cape Town.

Gerring, J., 2006, Case study research principles and practices, Cambridge University Press, Cambridge.

Hänggi, H., 2003, 'Making sense of security sector governance', in H. Hanggi \& T. Winkler (eds.), Challenges of security sector Governance, pp. 3-23, LIT Verlag, Munster.

Heinecken, L., 2011, 'Defence, democracy and South Africa's civil-military gap', Scientia Militaria - South African Journal of Military Studies 33(1), 119-140. https://doi.org/10.5787/33-1-6

Heinecken, L., 2019, South Africa's post-apartheid military, UCT Press, Cape Town.

Modise, T., 2003, 'Parliamentary oversight of the South African Department of Defence', in L. Le Roux, M. Rupiya \& N. Ngoma (eds.), Guarding the guardians Parliamentary oversight and civil-military relations: The challenges for SADC National Treasury of South Africa, pp. 45-53, Institute for Security Studies, Pretoria.

National Treasury of South Africa, 2005, National Treasury Guideline for Legislative Oversight through Annual Reports, National Treasury, Pretoria.

Ngculu, J., 2003, 'The role of the parliamentary defence committees in ensuring effective oversight: The South African experience', in R. Williams, G. Cawthra \& D. Abrahams (eds.), Ourselves to know: Civil-military relations and defence transformation in Southern Africa, pp. 177-187, Institute for Security Studies, Pretoria.

Olson, D.M., Stapenhurst, R., Pelizzo, R. \& Von Trapp, L. (eds.), 2008, Legislative oversight and budgeting: A world perspective, World Bank, Washington, DC.
Parliament of South Africa, 1995, Standing rules for the National Assembly and for Joint Business and Proceedings of the National Assembly and the Senate, 2nd edn., Parliament of the Republic of South Africa, Cape Town.

Plaatjie, M. (ed.), 2011, Manual for parliamentary committees, Parliament of the Republic of South Africa, Cape Town.

PMG, 1998a, Joint Standing Committee on Defence, viewed 23 February 2017, from https://pmg.org.za/committee-meeting/6691/.

PMG, 1998b, Joint Standing Committee on Defence, viewed 23 February 2017, from https://pmg.org.za/committee-meeting/6704/.

PMG, 2001, Portfolio Committee on Defence and Military Veterans, viewed 23 February 2017, from https://pmg.org.za/committee-meeting/4612/.

PMG, 2004, Defence and Military Veterans: Meetings 2004, viewed 25 August 2017 from https://pmg.org.za/committee/87/?filter=2004.

PMG, 2005, White Paper \& Defence Review Restructuring: Briefing; Special Defence Account Amendment Bill: Adoption; Armscor Amendment Bill, viewed 25 August 2017, from https://pmg.org.za/committee-meeting/5236/.

Shaw, M., 1998, 'Parliamentary committees: A global perspective', The Journal of Legislative Studies 4(1), 225-251. https://doi.org/10.1080/13572339808420547

Sisulu, M., 2012, Address by Speaker Max Sisulu at the 2012 Consultative Seminar of the South African Legislative Sector, Parliament of the Republic of South Africa, Cape Town, March 14-16, 2012.

Yamamoto, H., 2007, Tools for parliamentary oversight - A comparative study of 88 national parliaments, Inter-Parliamentary Union, Geneva.

Yin, R.K., 2009, Case study research and applications, Sage, Los Angeles, CA. 